\title{
EFEK EKSTRAK SAMBILOTO (ANDROGRAPHIS PANICULATA NEES.) PADA EKSPRESI P53 DARI KANKER PAYUDARA TIKUS YANG DIINDUKSI DMBA
}

\author{
Yurika Sastyarina ${ }^{1)}$, Junaidi Khotib ${ }^{2)}$, Sukardiman ${ }^{3)}$ \\ Kelompok Bidang Ilmu Farmakologi, UP. Fakultas Farmasi Universitas Mulawarman, Samarinda \\ e-mail: ureeqa@gmail.com ${ }^{l)}$ \\ Departemen Farmasi Klinik Fakultas Farmasi Universitas Airlangga, Surabaya ${ }^{2)}$ \\ Departemen Farmakognosi dan Fitokimia Fakultas Farmasi Universitas Airlangga, Surabaya ${ }^{3)}$
}

\begin{abstract}
It has been well documented that chemical carcinogen, 7.12 dimethylbenz-(a)anthracene (DMBA), plays a role in the incidence and growth of mammary cancer. Present study was designed to investigate the influence of Andrographis paniculata extract on telomerase activities on DMBA induced breast cancer in the female rat Sprague Dawley strain. DMBAinduced mammary cancer is a useful model to investigate the changes of epithelial cells that occur during mammary cancer progression. Mammary cancer model was induced 10 times twice a week by oral DMBA $20 \mathrm{mg} / \mathrm{kg}$ body weight. Mammary cancer occurred in $75 \%$ animals nine weeks after oral administration of DMBA, it was represented with nodule on the mammary gland and the increasing of mammary gland volume compare with normal control $F_{(1.8)}=731.711 ; p<0.001$. This study was also designed to investigate the effect of Andrographis paniculata extract mammary carcinoma induced by DMBA. Administration of three different dose of Andrographis paniculata (100 mg/kg, $300 \mathrm{mg} / \mathrm{kg}$ and $1000 \mathrm{mg} / \mathrm{kg}$ ) had statistically different with mammary gland volume of DMBA treated rat $F_{(4.17)}=92.777$; $p<0.05$. So, Andrographis paniculata has significant effect on the treatment of DMBA-induced mammary carcinoma. The Epithelial cells were harvested on day 90 and stained with routine histology staining, hematoxylineosin, for morphological qualitative analysis, immunohistochemical examination. The lesions observed from the removed samples ranged widely from benign to malignant. The results showed that DMBA induce cell proliferation, nuclear irregularities, and numerous mitoses and induced cell necrosis. On immunohistochemical examination, it shows that Andrographis paniculata can stimulate of expression of 53 protein and increase the number of epithelial cells experience apoptosis.
\end{abstract}

Key words: Sambiloto (Andrographis Paniculata Ness), DMBA, mammary cancer, p53

\begin{abstract}
ABSTRAK
Telah terdokumentasi dengan baik bahwa karsinogen kimia, 7,12 dimetilbenz(a)antrasena (DMBA), berperan dalam kejadian dan perkembangan kanker payudara. Penelitian ini dirancang untuk mengetahui pengaruh ekstrak Andrographis paniculata ekspresi p53 dan apoptosis pada kanker payudara tikus strain Sprague Dawley yang diinduksi DMBA. Kanker Payudara yang diinduksi DMBA adalah sebuah model yang berguna untuk mengetahui perubahan sel epitel yang terjadi selama perkembangan kanker payudara. Model Kanker Payudara diinduksi DMBA secara per oral 20 mg / kg 10 kali yaitu dua kali seminggu. Kanker Payudara terjadi pada $75 \%$ hewan pada sembilan minggu setelah pemberian oral DMBA, Hal
\end{abstract}


itu diwakili dengan benjolan pada kelenjar susu dan meningkatnya volume kelenjar susu dibandingkan dengan $\mathrm{F}$ kontrol $(1,8)=731.711 ; \mathrm{p}<0,001$. Penelitian ini juga dirancang untuk mengetahui pengaruh ekstrak Andrographis paniculata pada kanker payudara yang diinduksi oleh DMBA. Pada pemeriksaan imunohistokimia, hal itu menunjukkan bahwa sambiloto dapat menurunkan enzim telomerase, meningkatkan ekspresi protein p53 dan meningkatkan jumlah apoptosis sel epitel.

Kata Kunci: Sambiloto (Andrographis Paniculata. Ness), DMBA, Kanker payudara, p53

\section{PENDAHULUAN}

Kanker (Karsinoma) merupakan suatu penyakit kompleks yang tejadi karena adanya perubahan yang mendasar dalam fungsi biologis sel sehingga menjadi mandiri dalam signal pertumbuhan, tidak peka terhadap sinyal anti pertumbuhan, resisten terhadap apoptosis, defek pada perbaikan DNA, memiliki potensi replikasi yang tidak terbatas, angiogenesis, invasi dan metastasis ke jaringan lain [1].

Kanker payudara adalah keganasan tersering dan penyebab kematian tertinggi pada wanita di dunia karena kanker. The US Centre for Disease Control and Prevention melaporkan bahwa di Amerika Serikat kanker payudara menempati peringkat ketujuh dari sepuluh besar penyebab kematian pada wanita [2]. Sampai saat ini belum ada data statistik yang akurat di Indonesia, namun dari data berbagai rumah sakit yang ada menunjukkan bahwa ditemukan 100 per 100.000 penduduk yang terserang kanker payudara. Selain itu kanker payudara menduduki urutan kedua dari seluruh keganasan pada wanita [3].

Penatalaksanaan kanker payudara dilakukan dengan se-rangkaian pengobatan meliputi pem-bedahan untuk mengangkat jaringan kanker jika memungkinkan dan diikuti dengan terapi radiasi sinar-X intensitas tinggi untuk membunuh sel kanker yang tidak terangkat pada saat pembedahan, kemoterapi dengan menggunakan obat-obatan dan reseptor hormonal. Pengobatan ini ditujukan pada upaya pengangkatan jaringan, memusnahkan sel kanker atau membatasi perkembangan penyakit serta menghilangkan gejala-gejalanya dan meminimalkan efek yang tidak diinginkan terhadap sel normal [4]. Namun pada kenyataannya masih banyak obat kanker yang bekerja tidak selektif dimana selain membunuh sel kanker juga mem-bunuh sel normal serta menimbulkan efek samping yang merugikan sehingga Salah satu upaya yang dilakukan untuk mengatasi masalah tersebut adalah pencarian dan penemuan senyawa bioaktif dari tanaman obat Indonesia yang memiliki aktivitas antikanker, khususnya terhadap kanker payudara [5-7].

Sambiloto mengandung zat pahit andrografolida suatu senyawa diterpenoid yang diketahui memiliki efek antitumor. Peran antitumor andrografolida antara lain pada induksi apoptosis (kematian sel yang terprogram secara fisiologis) dan cell cycle arrest [1].

Adanya aktivasi p53 oleh Andrografolida melalui peningkatan fosforilasi p53 yang selanjutnya akan mempengaruhi proses siklus sel sehingga sel tidak akan mengalami pembelahan dan sel akan mati karena terjadi kondensasi kromosom yang menyebabkan terjadinya apoptosis [7] sehingga berdasarkan dari penelitian tersebut maka diduga ekstrak sambiloto mempunyai aktivitas peningkatan protein 
p53 pada sel tumor. Dengan pendekatan patobiologi penelitian ini dilakukan untuk mengungkap adanya permasalahan terkait ekspresi dari telomerase tikus betina galur SD (Sprague-Dawley) yang diinduksi kanker payudara oleh DMBA menggunakan metode imuno-histokimia yang diharapkan dapat menjelaskan mekanisme sambiloto (Andrographis paniculata Nees) dalam peranannya sebagai antikanker pada peningkatan protein $\mathrm{p} 53$.

\section{METODE}

\section{Bahan uji}

Bahan uji yang dipakai dalam penelitian ini adalah ekstrak sambiloto (Andrographis paniculata Nees) yang diperoleh dari IKOT Tradimun Gresik. Untuk pembuatan model kanker payudara digunakan penginduksi 7,12-dimethylbenz anthracene (DMBA) (Sigma Chem.).

\section{Subyek uji}

Hewan uji yang digunakan adalah tikus putih betina galur Sprague dawley (SD), umur 30-40 hari, berat badan berkisar 60200 gram. Sampel diperoleh dari Laboratorium Hewan Universitas Airlangga

\section{Induksi karsinogenesis dengan DMBA dan perlakuan dengan ekstrak sambiloto (Andrographis paniculata Nees)}

Dua puluh lima ekor tikus putih betina usia 30-40 hari dibagi menjadi lima kelompok secara random. Kelompok I sebagai kontrol (diberi makanan kontrol, yaitu pellet AD produksi PT COMFED Surabaya, kelompok II (perlakuan DMBA saja), Kelompok III, IV dan V (perlakuan setelah tahap karsinogenesis dengan pemberian ekstrak sambiloto). Inisiasi DMBA diberikan 2 kali seminggu dengan dosis 20 $\mathrm{mg} / \mathrm{kg}$ BB selama 5 minggu. Kelompok III, IV dan $\mathrm{V}$ diberi ekstrak sambiloto dengan dosis masing-masing 100, 300 dan 1000 $\mathrm{mg} / \mathrm{kg} \mathrm{BB}$ selama enam minggu. Tikus ditimbang setiap minggunya dan mulai minggu ke-1 setelah pemberian DMBA dilakukan palpasi setiap minggu untuk mengetahui perkembangan tumor sampai minggu ke-8.

\section{Pemeriksaan Hispatologi dan Uji Imunohistokimia}

Setelah pengamatan palpasi selesai, hewan dikorbankan 48 jam setelah pemberian sampel uji kemudian jaringan tumor diambil dan dibersihkan pembuluh darah serta lemak sekitranya untuk diukur volume tumornya. Jaringan ke-mudian dipreparasi dengan melakukan fiksasi menggunakan neutral buffered formalin dan dibuat sediaan. Sediaan terdiri dari dua yaitu sediaan dengan pewarnaan Hematoxyline Eosin terhadap organ mammae, untuk mengetahui keadaan sitologinya serta tingkat keparahan tumor atau kanker yang terjadi dan sediaan untuk imunohistokimia yang mana untuk uji imunohistokimia potongan ditempatkan dalam beberapa object glass yang telah diberi polylisine untuk selanjutnya dilakukan pemrosesan untuk pemeriksaan ekspresi protein p53 dengan pengecatan secara imuno-histokimia. Slide yang telah diwarnai, diamati dengan mikroskop cahaya dengan pembesaran 400 kali.

\section{Analisis data}

Insidensi tumor dihitung dari jumlah tikus yang terkena tumor pada tiap kelompok dengan mengukur volume dan berat tumor serta pada uji imunohistokimia penghitungan sel yang positif terwarnai dilakukan dengan metode skoring Allred Score. 


\section{HASIL DAN PEMBAHASAN}

\section{Pengaruh pemberian ekstrak sambiloto terhadap berat badan}

Perkembangan berat badan tikus masingmasing kelompok dapat dilihat dalam gambar 1 dan 2 yang merupakan hasil penimbangan berat badan setiap minggu. Dari gambar 1 tersebut dapat dilihat bahwa pemberian DMBA tidak mempengaruhi pertumbuhan normal tikus yang hanya diberi corn oil dan pada gambar 2 dari pemberian ekstrak sambiloto setelah induksi DMBA tidak mempengaruhi pertumbuhan normal tikus. Hal ini dikarenakan masing-masing kelompok suatu saat terjadi kemungkinan dikarenakan jumlah makanan dan minuman yang dikonsumsi sebelum dilakukan penimbangan, kondisi lingkungan dan stress akibat perlakuan.

\section{Pengaruh pemberian ekstrak sambiloto terhadap volume kelenjar payudara tikus}

Hasil penelitian efek anti-kanker ekstrak sambiloto (Andro-graphis paniculata Nees) pada kanker payudara tikus. Prevalensi kanker dapat dilihat dari munculnya nodul pada masing-masing kelenjar payudara dan terutama setelah dilakukan pengorbanan terhadap hewan yaitu dengan mengukur volume kelenjar payudara model kanker yang berbeda dengan kelompok normal dan kelompok uji. Rata-rata volume kelenjar payudara serta prevalensi kanker payudara pada tikus akibat induksi DMBA dapat dilihat gambar 3. Dari gambar 3 dapat dijelaskan bahwa terdapat perbedaan volume kelenjar payudara antara kelompok normal dan yang di induksi DMBA. Dimana berdasarkan hasil palpasi dan pengukuran volume kelenjar payudara, didapatkan prevalensi kanker payudara $75 \%$. Berdasarkan analisa statistik melalui uji ANOVA satu arah pada kelompok normal, model kanker (DMBA) dan sampel uji berbagai dosis menunjukkan perbedaan volume secara bermakna dengan $\mathrm{p}<0,001$.

Pengaruh pemberian ekstrak terhadap perubahan morfologi, apoptosis dan proliferasi pada sel-sel epitel kelenjar payudara tikus.

Dalam mengetahui perubahan morfologi, apoptosis dan proliferasi pada sel-sel epitel kelenjar payudara tikus, maka dilakukan pembedahan tikus dan diambil kelenjar payudara dari masing-masing kelompok untuk dipreparasi secara histokimia dengan pewarnaan Hematoxylin-Eosin.

Perbedaan gambaran histo-patologi kelenjar payudara antara normal dengan hewan yang mendapatkan induksi DMBA kemudian dengan ekstrak sambiloto masing-masing dosis dapat dilihat pada gambar 3. Pada gambar 4, hewan yang diberi treatment sambiloto $100 \mathrm{mg} / \mathrm{kg} \mathrm{BB}$ (B), sel tumor tampak berkurang dibanding dengan hewan yang dipapar DMBA (A) dan juga tampak sitoplasma yang lebih merah karena adanya fragmentasi inti akibat apoptosis, bentukan kelenjar mulai jelas, sel lemak mulai tampak dan diantara kelompok sel timbul jaringan ikat sehingga sel tumor yang terlokalisir. Pada irisan melintang ke-lenjar payudara hewan yang di treatment dengan sambiloto $300 \mathrm{mg} / \mathrm{kg}$ BB (C), disini juga tampak sitoplasma yang lebih merah akibat fragmentasi inti akibat apoptosis, jaringan ikat mulai terlokalisir lebih jelas dan sel tumor berkurang serta banyak sel tumor mati dan diisi oleh jaringan fibroblast. Disini juga tampak nekrosis yang ditandai dengan warna kemerahan berupa sel kosong. Pada irisan kelenjar payudara hewan yang di treatment dengan sambiloto $1000 \mathrm{mg} / \mathrm{kg}$ BB (D), tampak sel kelenjar mulai tersusun homogen dan berkurangnya bentukan inti 
pleumorfik dan juga tampak nekrosis yang ditandai dengan warna kemerahan dan tidak ada sel.

\section{Pengaruh ekstrak sambiloto terhadap p53 dan apoptosis dengan uji imunohistokimia}

Protein p53 berperan menginduksi hambatan pertumbuhan, reparasi DNA atau apoptosis pada respon stres seluler p53. Untuk melihat ekspresi protein p53, dilakukan tahapan proses imunohistokimia yang sama seperti pada imunohistokimia telomerase dengan menggunakan antibodi p53. Hasil analisis gambar dan data skoring terdapat pada gambar 1 dan tabel 1 .

Hasil ekspresi p53 (ditunjukkan oleh anak panah d dari gambar 2 pada kelompok yang diberi ekstrak sambiloto $100 \mathrm{mg} / \mathrm{kg}$ BB lebih banyak secara nyata dibandingkan dengan kelompok yang dipapar dengan DMBA dimana ekspresi p53 banyak terdapat pada membran sitoplasma dibanding inti sel, begitu pula dengan peningkatan dosis ekstrak sambiloto $300 \mathrm{mg} / \mathrm{kg} \mathrm{BB} \mathrm{(C)} \mathrm{dan} 1000 \mathrm{mg} /$ $\mathrm{kg}$ BB (D) yang mana ekspresi p53 makin tampak lebih banyak menutupi membran sitoplasma.

Hal ini disebabkan karena akumulasi p53 dalam sel yang timbul akibat penurunan kecepatan degradasi p53, sehingga waktu paruh p53 menjadi lebih panjang dan dengan bertambahnya ekspresi p53 ini maka dapat memberikan kesempatan untuk perbaikan DNA atau apoptosis.

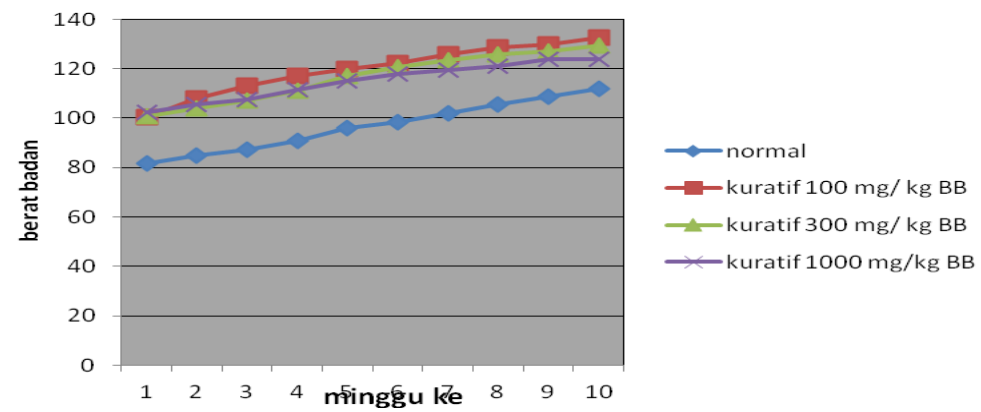

Gambar 1. Perkembangan berat badan tikus SD kelompok normal dan pemberian sampel uji masing-masing dosis (setelah induksi DMBA)

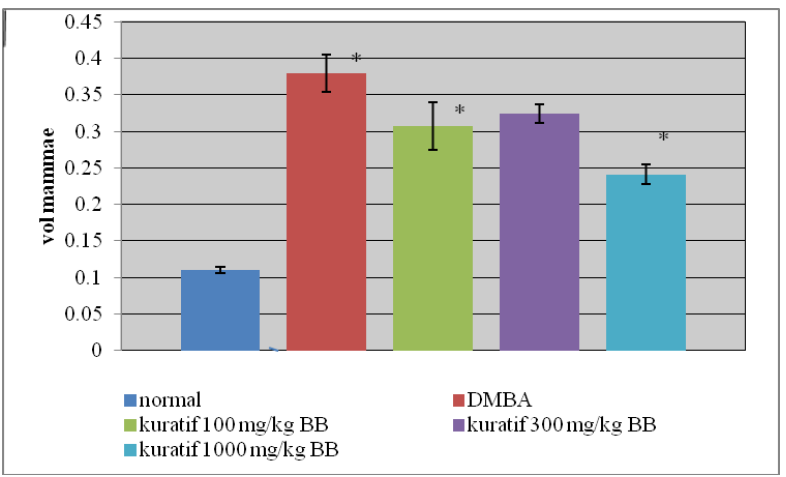

Gambar 2. Volume kelenjar payudara tikus SD pada kelompok normal, yang diinduksi DMBA dan pemberian ekstrak sambiloto

Ket : *)berbeda secara signifikan kelompok normal, DMBA vs $100 \mathrm{mg} / \mathrm{kg}$

$B B$ dan $1000 \mathrm{mg} / \mathrm{kg}$ BB dengan $\left.F_{(4,17)}=92,777 ; p<0,05\right)$ melalui uji anova satu arah 


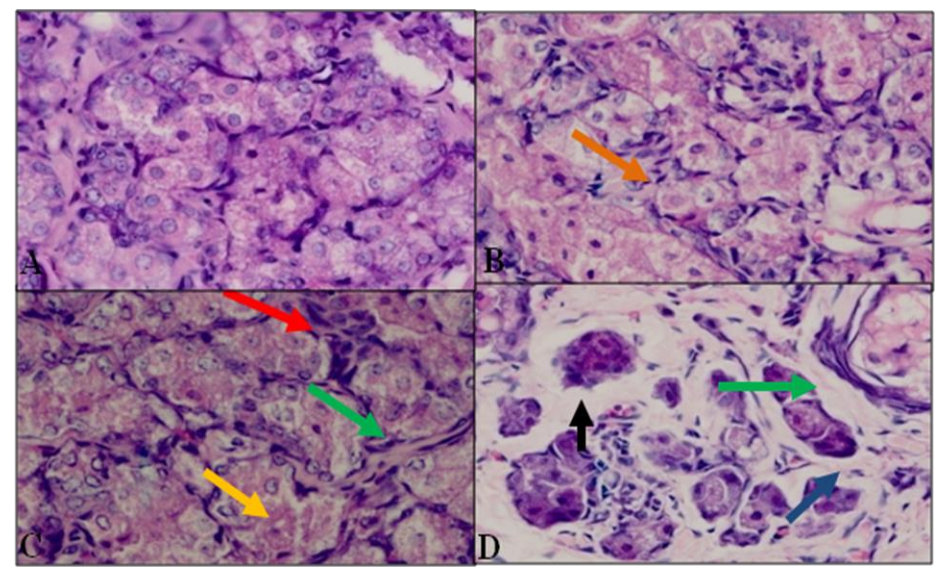

Gambar 3 Gambaran Histopatologi Kelenjar Payudara tikus SD Menggunakan Pewarnaan Hematoxylin-Eosin yang diberi Oleum Maydis (A) Ekstrak Sambiloto $100 \mathrm{mg} / \mathrm{kg} \mathrm{BB} \mathrm{(B).} \mathrm{Ekstrak} \mathrm{Sambiloto} 300 \mathrm{mg} / \mathrm{kg}$ $B B(C)$ Ekstrak Sambiloto $1000 \mathrm{mg} / \mathrm{kg}$ BB (D) (pembesaran $400 \mathrm{X}$ )

Keterangan: fragmentasi inti akibat apoptosis ( $\rightarrow$ ), jaringan ikat ( $\rightarrow$ ), nekrosis ( $\longrightarrow$ ), jaringan lemak $(\longrightarrow)$

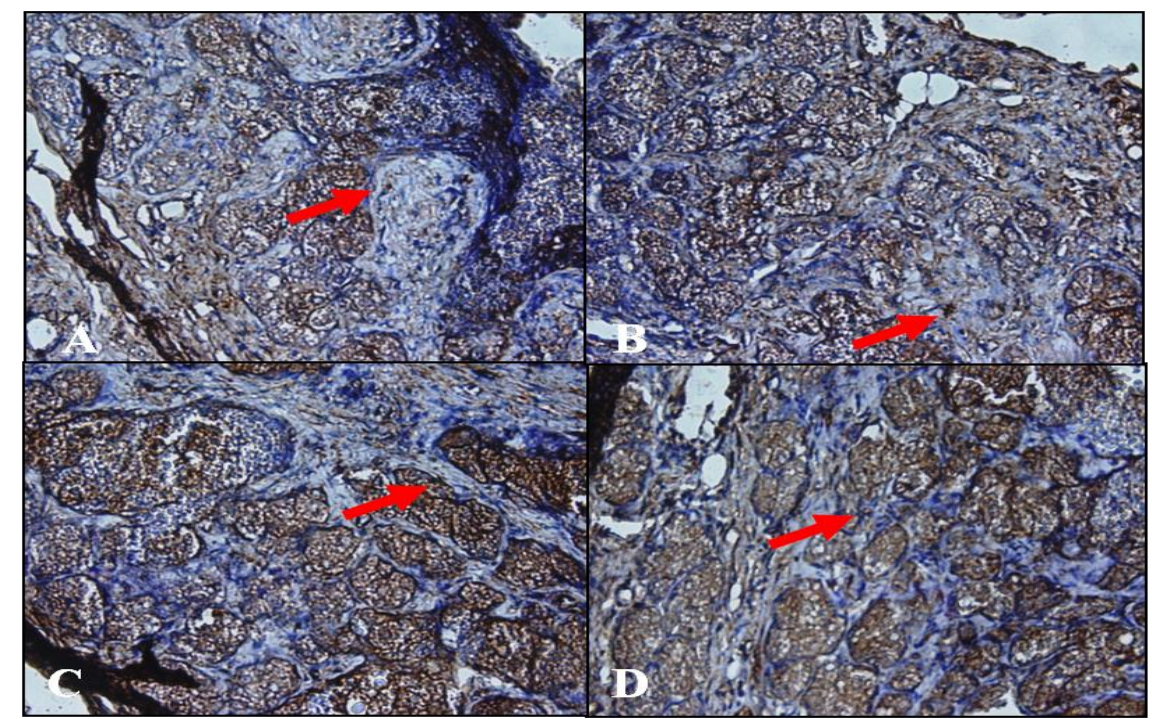

Gambar 3. Pewarnaan imunohistokimia menggunakan antibodi p53 pada irisan melintang kelenjar payudara tikus SD, dengan perbesaran 400x: yang diberi (A) DMBA, (B) ekstrak sambiloto $100 \mathrm{mg} / \mathrm{kg} \mathrm{BB,} \mathrm{(C)}$ ekstrak sambiloto $300 \mathrm{mg} / \mathrm{kg} \mathrm{BB}$, (D) ekstrak sambiloto $1000 \mathrm{mg} / \mathrm{kg} \mathrm{BB}$.

Keterangan : ekspresi p53( )

Tabel 1. Data Skoring Pengamatan Berdasarkan Metode Allred Score pada Irisan Melintang Kelenjar Payudara Tikus SD yang diberi Ekstrak Sambiloto dengan Pewarnaan Imunohistokimia Menggunakan Antibodi p53

\begin{tabular}{lc}
\hline \multicolumn{1}{c}{ Kelompok } & Skoring \\
\hline DMBA & 4 \\
Dosis $100 \mathrm{mg} / \mathrm{kg} \mathrm{BB}$ & 5 \\
Dosis $300 \mathrm{mg} / \mathrm{kg} \mathrm{BB}$ & 5 \\
Dosis $1000 \mathrm{mg} / \mathrm{kg} \mathrm{BB}$ & 5 \\
\hline
\end{tabular}


Pada perhitungan skoring dengan metode Allred score didapat ekspresi yang meningkat seiring denngan peningkatan dosis ekstrak sambiloto tetapi hal ini tidak dapat dihitung per sel tiap lapang pandang karena banyaknya akumulasi p53 pada membran sitoplasma (tabel 1).

\section{PEMBAHASAN}

Telah banyak dilakukan penelitian mengenai efek antikanker pada sambiloto khususnya kanker payudara, dan telah didapatkan hasil bahwa senyawa yang terkandung di dalam ekstrak sambiloto yaitu andrografolida. Pemberian ekstrak sambiloto pada percobaan ini dapat mengurangi tingkat progresifitas tumor setelah inisiasi DMBA. Adanya hambatan ini dimungkinkan karena daya hambatan perkem-bangan tumor tahap awal melalui modulasi proliferasi sel. Andro-grafolida yang terkandung dalam ekstrak mampu menghambat pertumbuhan nodul tumor, me-ningkatkan apoptosis dan menginhibisi proliferasi sel. Hasil ini juga sesuai dengan yang ditunjukkan pada sifat sitotoksiknya pada kanker payudara. Andrografolida dalam ekstrak sambiloto juga dapat menghambat efek DNA topoisomerase II sehingga proses replikasi, transkripsi dan proliferasi sel mengalami penurunan [8], menginduksi inhibitor sel, p27 dan cyclin dependent kinase inhibitor (cdki) [8] serta meningkatkan induksi apoptosis melalui reseptor kematian dari tumor necrosis factor-related apoptosis inducing ligand) [9]. Adanya aktivasi p53 oleh Andrografolida melalui stabilisasi p53 yang selanjutnya akan mempengaruhi proses siklus sel sehingga sel tidak akan mengalami pembelahan dan sel akan mati karena terjadi kondensasi kromosom yang menyebabkan terjadinya apoptosis sehingga berdasarkan dari penelitian tersebut maka diduga ekstrak sambiloto mempunyai aktivitas antimitosis dan propoptosis pada sel tumor. Obat yang mempunyai efek antimitosis diduga juga mempunyai efek antitelomerase yang dapat menghambat pembelahan dan perkembangan sel yang sangat cepat seperti sel kanker dan berakibat terjadi kematian sel (apoptosis) [10].

Protein p53 merupakan protein penghambat siklus sel yang dalam bentuk normal adalah tipe wild (p53 wild type) yang terdapat di dalam inti dan berfungsi untuk menghambat mitosis dengan jalan memblok siklus sel pada fase G1. Pada penelitian Weng dan Hodes menyebutkan bahwa adanya hubungan yang sinergis antara hambatan pada pembentukan enzim telomerase dan peningkatan protein p53.

Adanya hambatan pada proses mitosis ini mengakibatkan penurunan aktivitas telomerase oleh p53 melalui jalur p21 pada penurunan transkripsi dari protein human telomerase reverse transcriptase (hTERT). Adanya inaktivasi gen penekan tumor merupakan kunci penting awal kejadian karsinogenesis pada kanker payudara. Protein ini berperan menginduksi hambatan pertumbuhan, reparasi DNA atau apoptosis pada respon stress seluler. Protein p53 sendiri mempunyai dua tipe yaitu $p 53$ wildtype dan p53 mutant. Wild-type p53 secara alami terdapat dalam sel normal dan mempunyai waktu paruh kurang dari 30 menit dan konsentrasinya rendah jika terjadi kerusakan DNA, konsentrasi ini akan bertambah dan berfungsi menghambat siklus sel pada fase G1, sehingga memberi kesempatan untuk perbaikan DNA atau apoptosis. Pada kelompok yang diberi oleum maydis atau kelopok normal perbesaran 400x (A), ekspresi p53 tampak sedikit dibanding dengan kelompok yang dipapar DMBA (D), ini dapat dilihat dari membran selnya yang berwarna biru. Protein p53 pada sel normal dijaga agar kadarnya tetap rendah atau tidak aktif. 
Protein p53 yang aktif atau bebas pada sel normal mempunyai waktu paruh yang sangat pendek yaitu 20-30 menit. Hal tersebut mengakibatkan p53 sulit dideteksi pada sel normal. Ekspresi p53 pada kelompok normal, kemungkinan disebabkan oleh false positif pada pengecatan dan pemrosesan jaringan. Sedangkan pada kelompok hewan yang dipapar DMBA (B), ekspresi protein p53 nampak di sekitar sel-sel epitel duktus yaitu di inti sel dan membran sitoplasma. Hal ini menunjukkan bahwa kerusakan DNA memicu peningkatan p53. Sedangkan hasil ekspresi p53 dari gambar 1 pada kelompok yang diberi ekstrak sambiloto $100 \mathrm{mg} / \mathrm{kg}$ BB lebih banyak secara nyata dibandingkan dengan kelompok yang dipapar dengan DMBA dimana ekspresi p53 banyak terdapat pada membran sitoplasma dibanding inti sel, begitu pula dengan peningkatan dosis ekstrak sambiloto $300 \mathrm{mg} / \mathrm{kg} \mathrm{BB}$ (C) dan $1000 \mathrm{mg} /$ $\mathrm{kg}$ BB (D) yang mana ekspresi p53 makin tampak lebih banyak menutupi membran sitoplasma.

Hal ini disebabkan karena akumulasi p53 dalam sel yang timbul akibat penurunan kecepatan degradasi p53, sehingga waktu paruh p53 menjadi lebih panjang dan dengan bertambahnya ekspresi p53 ini maka dapat memberikan ke-sempatan untuk perbaikan DNA atau apoptosis. Pada perhitungan skoring dengan metode Allred score didapat ekspresi yang meningkat seiring denngan peningkatan dosis ekstrak sambiloto tetapi hal ini tidak dapat dihitung per sel tiap lapang pandang karena banyaknya akumulasi p53 pada membran sitoplasma.

\section{KESIMPULAN}

Ekstrak sambiloto (Andro-graphis paniculata Nees) dapat me-ningkatkan ekspresi protein p53 pada sel-sel kelenjar payudara yang diinduksi menjadi kanker payudara dengan 7,12-dimethlbenz(a) anthra-cene (DMBA) setelah diterapi ekstrak sambiloto (Andrographis paniculata Nees) sehingga ber-potensi sebagai senyawa antikanker payudara.

\section{UCAPAN TERIMA KASIH}

Terima kasih diucapkan kepada UP. Fakultas Farmasi Universitas Mulawarman yang telah membiayai penelitian ini dan Universitas Airlangga atas penyediaan fasilitas dalam penelitian ini.

\section{DAFTAR PUSTAKA}

1. Kumar, R.A.; Sridevi, K.; \& Kumar, N.V. 2004, Anticancer and Immu-nostimulatory Compounds from Andrographis Pani-culata. $J$. Ethno-pharmacology 92(2-3):291-95

2. American Cancer Society, Inc. 2008, What You Can Do About Breast Cancer, http://www. cancer.org/docroot/CRI/content/CRI_2_4_1X_ What_is_breast_cancer_5. asp, 19 Juli 2009.

3. Kusumowardojo.; Panuwun, T. 2004, Beberapa Aspek Sitologi \& Histologi Kanker Payudara, Indonesian Issue on Breast Cancer I. Surabaya, 1-17.

4. King, R.J.B. 2000, Cancer Biology, $2^{\text {nd }}$ ed. Harlow-England-London-New York: Pearson Education, pp.263-64

5. Ganiswara.; Sulistia, G.; dkk. 1995, Farmakologi dan Terapi edisi 4. Bagian Farmakologi, Fakultas Kedokteran Universitas In-donesia; Jakarta. Hal. 686-701.

6. Meiyanto, E.; Tasminatun, S.; Susilowati, S.; Murwanti, R.; \& Sugiyanto. 2007, Penghambatan Karsinogenesis Ka-nker Payudara Tikus Ter-induksi DMBA pada Fase Post Inisiasi oleh Ekstrak Etanolik daun Gynura procumbens (Lour), Merr. Majalah Farmasi Indonesia. 18(4), 169-175

7. Sukardiman. 2007, Meka-nisme Induksi Apoptosis Pinaostrobin dari Kaemferia pandurata Roxb dan Andro-grafolida dari Andrographis paniculata Nees terhadap Sel Kanker Manusia Secara In Vitro dan Implikasinya Pada Penggunaan Secara In Vivo. Disertasi, Universitas Air-langga; Surabaya.

8. Sukardiman. Hadi, P.; Sofia, M.; \& Sismindari. 2000, Penapisan Senyawa Anti-kanker dari Tanaman Obat Indonesia dengan Molekul 
Efek Ekstrak Sambiloto (Andrographis paniculata nees.) pada Ekspresi p53 dari Kanker Payudara Tikus yang Diinduksi DMBA

Target Enzim DNA Topo-isomerase. Laporan Akhir Penelitian Domestic Colla-borative Research Grant

9. Zhou, J.; Lu, G.; Ong, C.; \& Shen,H. 2008. Andrographolide Sensitizes Cancer Cells to
TRAIL-Induced Apoptosis via p53-mediated Death Receptor 4 Up-regulation. Molecular cancer Thera-peutics 7:2170-180

10. Anonim. 2004, Terapi Telomerase Atasi Kanker Hati. Surya, Maret 15 Surabaya. 